\title{
Mechanism Underlying the Aluminum-Induced Stimulation of Bone Nodule Formation by Rat Calvarial Osteoblasts
}

\author{
Hiroyuki Kaneki, ${ }^{*}, a$ Keiko Ishibashi, ${ }^{a}$ Minoru Kurokawa, ${ }^{b}$ Masaki Fujieda, ${ }^{a}$ Michiaki Kiriu, ${ }^{a}$ \\ Shigeki Mizuochi, ${ }^{a}$ and Hayao Ide ${ }^{a}$
}

${ }^{a}$ Department of Hygienic Chemistry, Faculty of Pharmaceutical Sciences, Toho University, 2-2-1 Miyama, Funabashi, Chiba 2748510, Japan and ${ }^{b}$ Department of Pharmacy, Omori Hospital, Faculty of Medicine, Toho University, 5-21-16 Omorinishi, Ota-ku, Tokyo 143-8540, Japan

(Received September 13, 2003; Accepted September 22, 2003)

\begin{abstract}
The signal transduction mechanism for aluminum $\left(\mathrm{Al}^{3+}\right)$-induced stimulation of bone formation and its crosstalk with the prostaglandin $\mathrm{E}_{2}\left(\mathrm{PGE}_{2}\right)$ signaling pathway were studied in calvarial osteoblasts from 25-week-old rats (MOB) and those from 90-week-old rats (AOB). Alkaline phosphatase activity, the rate of $\left[{ }^{3} \mathrm{H}\right]$ proline incorporation into collagenase-digestible proteins, the total area and number of mineralized bone nodules (BN) and the content of calcium in $\mathrm{BN}$, which are the markers for differentiation of osteoblasts, were dose-dependently stimulated by the treatment with $\mathrm{Al}^{3+}$ at a concentration range of $10^{-7}-10^{-5} \mathrm{M}$ in the cultures of both MOB and AOB. The stimulatory effects of $\mathrm{Al}^{3+}$ on the differentiation markers were abolished by the pretreatment of the cells with pertussis toxin (PTX), an inhibitor of $\mathrm{G}_{\mathrm{i}}$ protein, indicating that the effects of $\mathrm{Al}^{3+}$ are mediated through a receptor coupled with $\mathrm{G}_{\mathrm{i}}$ protein. $\mathrm{Al}^{3+}$ increased inositol-1,4,5-triphosphate $\left(\mathrm{IP}_{3}\right)$ production and intracellular concentration of $\mathrm{Ca}^{2+}\left(\left[\mathrm{Ca}^{2+}\right]_{i}\right)$ in the cultures of MOB and AOB: these effects were not observed in the presence of PTX, indicating that the effects of $\mathrm{Al}^{3+}$ are mediated through the activation of phosphatidylinositol-specific phospholipase C (PI-PLC). We have previously shown that 17-phenyl- $\omega$-trinor- $\mathrm{PGE}_{2}$, a selective agonist for an $\mathrm{EP}_{1}$ subtype of $\mathrm{PGE}_{2}$ receptor $\left(\mathrm{EP}_{1}\right)$, stimulates the differentiation markers in the cultures of MOB through the activation of PI-PLC, but not in those of AOB because of the lack of $\mathrm{EP}_{1}$. The levels of the differentiation markers obtained in the presence of the $\mathrm{EP}_{1}$ agonist were increased by the addition of $\mathrm{Al}^{3+}$ in the cultures of $\mathrm{MOB}$ and $\mathrm{AOB}$, while $\mathrm{Al}^{3+}$ increased the levels of $\mathrm{IP}_{3}$ production and $\left[\mathrm{Ca}^{2+}\right]_{i}$ in the presence of the $\mathrm{EP}_{1}$ agonist only in the cultures of AOB. These results indicate a possibility that PIPLC molecules stimulated by the signal through $\mathrm{G}_{\mathrm{i}}$ protein and those stimulated by the signal through $\mathrm{EP}_{1}$ belong to the same pool and that the $\mathrm{Al}^{3+}$ signal through $\mathrm{G}_{\mathrm{i}}$ protein induces cell differentiation via a pathway(s) independent of

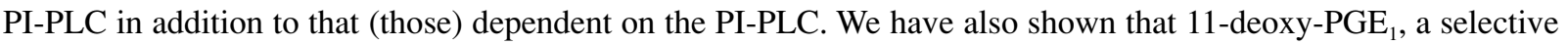
agonist for an $\mathrm{EP}_{2} / \mathrm{EP}_{4}$ subtype of $\mathrm{PGE}_{2}$ receptor $\left(\mathrm{EP}_{2} / \mathrm{EP}_{4}\right)$, inhibits cell differentiation in the cultures of both $\mathrm{MOB}$ and $\mathrm{AOB} . \mathrm{Al}^{3+}$ had no effect on the basal levels of cAMP production, but the levels induced by the $\mathrm{EP}_{2} / \mathrm{EP}_{4}$ agonist were dose-dependently reduced by the treatment with $\mathrm{Al}^{3+}$ at a concentration range of $10^{-7}-10^{-5} \mathrm{M}$. The inhibitory effect of $\mathrm{Al}^{3+}$ on adenylyl cyclase was abolished by the pretreatment with PTX. These results indicate that $\mathrm{Al}^{3+}$ suppresses adenylyl cyclase activity induced by the $\mathrm{EP}_{2} / \mathrm{EP}_{4}$-mediated signal through the $\mathrm{G}_{\mathrm{i}}$ protein-coupled receptor.
\end{abstract}

Key words — aluminum, osteoblast, bone formation, prostaglandin $\mathrm{E}_{2}$, signal transduction, $\mathrm{G}_{\mathrm{i}}$ protein

\section{INTRODUCTION}

Exposure to aluminum $\left(\mathrm{Al}^{3+}\right)$ has been associated with aplastic bone lesion and osteomalacia characterized by decreased mineralization of osteoid in

*To whom correspondence should be addressed: Department of Hygienic Chemistry, Faculty of Pharmaceutical Sciences, Toho University, 2-2-1 Miyama, Funabashi, Chiba 274-8510, Japan. Tel.: +81-474-72-1834; Fax: +81-474-72-1828; E-mail: kaneki@ phar.toho-u.ac.jp patients with chronic renal failure undergoing hemodialysis and in those under long-term medication of $\mathrm{Al}^{3+}$-containing phosphate binders. ${ }^{1-4)}$ However, the mechanism by which $\mathrm{Al}^{3+}$ produces the osteodystrophy is controversial. Decreased numbers of osteoblasts and accumulation of $\mathrm{Al}^{3+}$ at the mineralization front have been observed in human biopsy samples $^{5-7)}$ and in bone tissues from experimental animal models ${ }^{8}{ }^{8}$ suggesting that $\mathrm{Al}^{3+}$ may physicochemically inhibit the formation and growth of hy- 
droxylapatite crystals and/or inhibit mineralization through the action on osteoblasts. The involvement of a relative deficiency of circulating parathyroid hormone has also been suggested in the pathogenesis of $\mathrm{Al}^{3+}$-induced osteomalacia. ${ }^{6,9)}$

Conflicting results have also been obtained as to the effect of $\mathrm{Al}^{3+}$ on proliferation and differentiation of osteoblasts from in vitro studies. ${ }^{10-17)}$ Thus, several investigators reported that $\mathrm{Al}^{3+}$ decreases the parameters of proliferation and differentiation in the cultures of mouse calvarial cells ${ }^{10)}$ and clonal osteoblasts-like cell lines such as UMR106-01 ${ }^{11)}$ and ROS $17 / 2.8,{ }^{12)}$ but others reported stimulatory effects of $\mathrm{Al}^{3+}$ on these parameters in the cultures of rat ${ }^{13)}$ and chicken ${ }^{14)}$ calvarial cells, human normal osteoblasts, ${ }^{14)}$ and clonal osteoblasts-like cell lines such as TE-85 ${ }^{14-16)}$ and MC3T3-E1. ${ }^{17)}$ The apparent discrepancy seems to be due to the difference in cells used, culture conditions, concentrations and time of addition of $\mathrm{Al}^{3+}$ and other experimental conditions. The purpose of the present study is to clarify the mechanism for changes in the properties of osteoblasts induced by $\mathrm{Al}^{3+}$ using the cultures of calvarial cells from young and aged rats.

In our previous report, we proposed a model of signal transduction for the activation of mineralized bone nodule $(\mathrm{BN})$ formation by prostaglandin $\mathrm{E}_{2}$ $\left(\mathrm{PGE}_{2}\right)$, a potent modulator of bone remodeling, in rat calvarial osteoblasts. ${ }^{18)}$ According to the model, $\mathrm{PGE}_{2}$ stimulates the production of cAMP, a suppressor of bone formation, by the $\mathrm{G}_{\mathrm{s}}$ protein-mediated activation of adenylyl cyclase through an $\mathrm{EP}_{2} / \mathrm{EP}_{4}$ subtype of $\mathrm{PGE}_{2}$ receptor $\left(\mathrm{EP}_{2} / \mathrm{EP}_{4}\right) . \mathrm{PGE}_{2}$ also activates calmodulin $(\mathrm{CaM})$ by the stimulation of phosphatidylinositol-specific phospholipase C (PIPLC) and subsequent increase in the intracellular $\mathrm{Ca}^{2+}$ concentration $\left(\left[\mathrm{Ca}^{2+}\right]_{i}\right)$ through an $\mathrm{EP}_{1}$ subtype of $\mathrm{PGE}_{2}$ receptor $\left(\mathrm{EP}_{1}\right)$. The activated CaM accelerates differentiation of osteoblasts and also stimulates phosphodiesterase to hydrolyze cAMP, resulting in the loss of the $\mathrm{EP}_{2} / \mathrm{EP}_{4}$-mediated signal. We therefore studied here the effect of $\mathrm{Al}^{3+}$ on $\mathrm{BN}$ formation in relation to the signaling pathway for $\mathrm{PGE}_{2}$ in the model described above. We also found in the previous study that $\mathrm{EP}_{1}$ is lost in osteoblasts from aged rats, by which $\mathrm{PGE}_{2}$ becomes inhibitory to the bone formation. We therefore used the cultures of calvarial cells isolated from 25-week-old rats (MOB) and those from 90-week-old rats (AOB) to determine the age-related changes in the mechanism of action of $\mathrm{Al}^{3+}$ on osteoblasts.

\section{MATERIALS AND METHODS}

Cell Culture — The cells enriched for osteoblasts phenotype were enzymatically isolated from calvariae of 25- and 90-week-old female Wistar rats (CLEA, Tokyo, Japan) according to the method described previously. ${ }^{18,19)}$ Briefly, frontal and parietal bones from the rats were minced with scissors and digested with a mixture of $0.2 \%$ collagenase (Wako Pure Chemical Industries, Tokyo, Japan) and $0.25 \%$ trypsin at $37^{\circ} \mathrm{C}$ for $20 \mathrm{~min}$. The released cells were collected and immediately suspended in F-12 medium (Invitrogen, MD, U.S.A.) supplemented with $15 \%$ fetal bovine serum (FBS, Invitrogen). This procedure was repeated further 5 times every $20 \mathrm{~min}$. The released cells from the last four populations, 36 , were cultured in F-12 medium supplemented with $10 \% \mathrm{FBS}$ at $37^{\circ} \mathrm{C}$. After reaching subconfluence, the cells were collected by a trypsin treatment, plated at a density of $2 \times 10^{3}$ cells $/ \mathrm{cm}^{2}$ in the same medium and cultured for 5 days. At the end of day 5, the medium was changed to $\alpha$-MEM medium (Invitrogen) supplemented with 10\% FBS, $5 \mathrm{mM} \beta$ glycerophosphate and ascorbic acid $(0.1 \mathrm{mg} / \mathrm{ml})$ and the cells were maintained for a further 23 days.

BN Formation — At the end of day 28, the cells in 4-well plates were washed three times with phosphate-buffered saline (PBS) and BN were visualized by von Kossa's staining as described previously. ${ }^{18,19)}$ The total number and area of BN were assessed using a colony counter (BMS-400: Toyo Sokki, Tokyo, Japan). For the determination of calcium content in $\mathrm{BN}$, the cells in 12-well plates were washed three times with PBS, scraped in $1 \mathrm{ml}$ of $1 \mathrm{M} \mathrm{HCl}$, incubated for $24 \mathrm{hr}$ with gentle shaking, and sonicated twice for $10 \mathrm{sec}$ with a sonicator (Ultrasonic Disruptor UD-201: Tomy Seiko, Tokyo, Japan). The calcium content in the sonicate was determined with the use of a commercial kit (Calcium test C Wako: Wako Pure Chemical Industries) based on the 3,3'-bis-[N,N-bis(carboxymethyl)aminomethyl]$o$-cresolphthalein method.

Determination of Collagen Synthesis — The cells in 12-well plates were washed twice with the serum-free $\alpha$-MEM medium at the beginning of day 7 and incubated for $5 \mathrm{hr}$ with the same medium containing $\left[2,3-{ }^{3} \mathrm{H}\right]$ proline $(1.5 \mu \mathrm{Ci} / \mathrm{ml})$. The cells were washed three times with cold PBS to remove unincorporated radioactivity, lysed by freeze-thawing, extracted in $0.5 \%$ Triton X-100, and precipitated with cold 10\% trichloroacetic acid (TCA). The acid-insoluble precipitates were collected by centrifugation 
at $3000 \mathrm{rpm}$ for $15 \mathrm{~min}$ at $4{ }^{\circ} \mathrm{C}$ and resuspended in $10 \%$ TCA to remove free $\left[2,3-{ }^{3} \mathrm{H}\right]$ proline. This washing procedure was repeated twice, and the amounts of collagenase-digestible proteins and noncollagenous proteins in the precipitates were measured according to the method of Peterkofsky and Diegelmann. ${ }^{20)}$ Briefly, each acid-insoluble protein was digested by highly purified collagenase (Sigma Chemicals, MO, U.S.A.) for $24 \mathrm{hr}$ at $37^{\circ} \mathrm{C}$ and the radioactivity in supernatants was counted using a liquid scintillation counter as the rate of [2,3$\left.{ }^{3} \mathrm{H}\right]$ proline incorporation into collagen.

Assay of Alkaline Phosphatase (ALP) Activity At the beginning of day 7, the cells in 24-well plates were washed three times with PBS, and sonicated twice in $0.3 \mathrm{ml}$ of $50 \mathrm{mM}$ Tris- $\mathrm{HCl}$ buffer (pH 7.2) containing $0.5 \%$ Triton X-100 and $2 \mathrm{mM}$ $\mathrm{MgCl}_{2}$ for $10 \mathrm{sec}$ at $4^{\circ} \mathrm{C}$ with the sonicator. The activity of alkaline phosphatase (ALP) in the sonicate was determined according to the method of Lowry et al. ${ }^{21)}$ with $p$-nitrophenylphosphate as a substrate. Cell Proliferation _ At the beginning of day 6, the cells in 24-well plates were washed twice with serum-free $\alpha$-MEM medium and incubated for $3 \mathrm{hr}$ in the same medium containing [methyl$\left.{ }^{3} \mathrm{H}\right]$ thymidine $(1.25 \mu \mathrm{Ci} / \mathrm{ml})$. The cells were washed three times with cold PBS to remove unincorporated radioactivity, followed by two washes of $10 \%$ TCA. The cell layers were solubilized in $1 \mathrm{M} \mathrm{NaOH}$, and aliquots of the solubilized cells were diluted into liquid scintillation fluid after neutralization with $1 \mathrm{M}$ $\mathrm{HCl}$, and counted using a liquid scintillation counter as the rate of [methyl $\left.-{ }^{3} \mathrm{H}\right]$ thymidine incorporation into the cells.

Radioimmunoassay (RIA) for $\mathbf{P G E}_{2}$ — At the beginning of day 5 , the cells in 24-well plates were incubated with $\mathrm{AlCl}_{3}$ for $24 \mathrm{hr}$ in serum- and $\mathrm{Zn}^{2+}$ free F-12 medium. After the incubation, $0.5 \mathrm{ml}$ of the medium was gently mixed with $0.5 \mathrm{ml}$ of $75 \%$ ethanol and $0.01 \mathrm{ml}$ of glacial acetic acid, and applied to an Amprep $\mathrm{C}_{18}$ column (100 mg size: Amersham Biosciences, NJ, U.S.A.), which had been primed with $3 \mathrm{ml}$ of $10 \%$ ethanol. After washing the column with $3 \mathrm{ml}$ of distilled water and $1.5 \mathrm{ml}$ of hexane, $\mathrm{PGE}_{2}$ was eluted with $3 \mathrm{ml}$ of ethyl acetate. The eluate was evaporated to dryness under a stream of nitrogen, and reconstituted with $0.1 \mathrm{ml}$ of phosphate buffered gelatin saline ( $\mathrm{pH}$ 7.0). As it is necessary for radioimmunoassay (RIA) to convert $\mathrm{PGE}_{2}$ into its methyl oximate derivative, the sample was incubated with methyloxylamine hydrochloride reagent (Amersham Biosciences) at $60^{\circ} \mathrm{C}$ for $1 \mathrm{hr}$. The amount of $\mathrm{PGE}_{2}$ in the sample was determined using a commercial RIA kit (Amersham Biosciences). Measurement of Inositol-1,4,5-Triphosphate (IP $\left.{ }_{3}\right)$ - The cells in 12-well plates were cultured in the serum- and $\mathrm{Zn}^{2+}$-free $\mathrm{F}-12$ medium for $24 \mathrm{hr}$ on day 5. During the last $1 \mathrm{hr}$ of the incubation, $10^{-2} \mathrm{M}$ $\mathrm{LiCl}$, an inositolphosphate phosphatase inhibitor, was included in the medium. The cells were treated with the same medium containing various concentrations of $\mathrm{AlCl}_{3}$ for $15 \mathrm{sec}$, scraped into $1 \mathrm{ml}$ of cold $15 \%$ TCA, and incubated for $20 \mathrm{~min}$ at $4^{\circ} \mathrm{C}$. After centrifugation at $3000 \mathrm{rpm}$ for $15 \mathrm{~min}$ at $4^{\circ} \mathrm{C}$, the supernatant was treated with water-saturated diethyl ether to remove TCA, neutralized with $0.1 \mathrm{M} \mathrm{NaOH}$, and applied to a wool-plugged Pasteur pipette column containing $2 \mathrm{~g}$ of anion exchange resin (AG1X8 formate: Bio-Lad Laboratories, CA, U.S.A.). Inositol-4-monophosphate, inositol-1,4-diphosphate, and inositol-1,4,5-triphosphate $\left(\mathrm{IP}_{3}\right)$ were sequentially eluted from the column by the addition of $8 \mathrm{ml}$ each of $0.1 \mathrm{M}$ formic acid containing $0.2,0.4$ and $1 \mathrm{M}$ ammonium formate, respectively. The amount of $\mathrm{IP}_{3}$ in the eluted fractions was determined using the use of a commercial RIA kit (Amersham Biosciences).

Measurement of Intracellular cAMP — The cells in 12-well plates were cultured in the serumand $\mathrm{Zn}^{2+}$-free $\mathrm{F}-12$ medium for $24 \mathrm{hr}$ on day 4. During the last $30 \mathrm{~min}$ of the incubation, $5 \times 10^{-4} \mathrm{M}$ IBMX, a phosphodiesterase inhibitor, was included in the medium. The cells were treated with the same medium containing various concentrations of $\mathrm{AlCl}_{3}$ for $20 \mathrm{~min}$, scraped into $1 \mathrm{ml}$ of cold $15 \%$ TCA, and incubated for $20 \mathrm{~min}$ at $4^{\circ} \mathrm{C}$. After centrifugation at $3000 \mathrm{rpm}$ for $15 \mathrm{~min}$ at $4^{\circ} \mathrm{C}$, the supernatant was treated with water-saturated diethyl ether to remove TCA, and neutralized with $0.1 \mathrm{M} \mathrm{NaOH}$. The amount of cAMP was determined using a commercial RIA kit (Yamasa, Chiba, Japan).

Measurement of $\left[\mathrm{Ca}^{2+}\right]_{i} \longrightarrow$ The cells in 12-well plates were cultured in the serum- and $\mathrm{Zn}^{2+}$-free $\mathrm{F}$ 12 medium for $24 \mathrm{hr}$ on day 4 . During the last $2 \mathrm{hr}$ of the incubation, $10^{-5} \mathrm{M}$ fra-2/AM, a chelating reagent for $\mathrm{Ca}^{2+}$, was included in the medium to hydrolyze the acetoxymethyl ester fra-2 completely. After the incubation, the cells were treated with various concentrations of $\mathrm{AlCl}_{3}$ for $15 \mathrm{sec}$ and the ratio of fluorescence intensity excited at $340 \mathrm{~nm}$ and $380 \mathrm{~nm}$ (500-nm emission) was measured with a Cyto Fluor II automatic plate-reading fluorimeter (PerSeptive Biosystems, Tokyo, Japan) according to the method of Grynkiewicz et al. ${ }^{22)}$ as described pre- 
Table 1. Sequences of Primers, PCR Conditions and Identity of PCR Products

\begin{tabular}{|c|c|c|c|c|c|}
\hline Gene & Primers $\left(5^{\prime} \rightarrow 3^{\prime}\right)$ & $\begin{array}{c}\mathrm{T} \\
\left({ }^{\circ} \mathrm{C}\right)\end{array}$ & $\begin{array}{l}\text { PCR } \\
\text { cycle }\end{array}$ & $\begin{array}{l}\text { Product size } \\
\text { (bp) }\end{array}$ & $\begin{array}{c}\text { Sequence homology } \\
(\%)\end{array}$ \\
\hline \multirow[t]{2}{*}{$\mathrm{EP}_{1}$} & F: AACCAAGAGTGCCTGGGAGG & 63 & 25 & 410 & 99 \\
\hline & R: GTTGCAAGAGTCTACTGTGGCG & & & & \\
\hline \multirow[t]{2}{*}{$\mathrm{EP}_{2}$} & F: TTCAATGACTCCAGGCGAGT & 56 & 25 & 540 & 98 \\
\hline & R: AGGACAGTACTGGACGTACT & & & & \\
\hline \multirow[t]{2}{*}{$\mathrm{EP}_{4}$} & F: ATGTCCATCCCCGGAGTCAA & 59 & 25 & 530 & 98 \\
\hline & R: AGTCGATGAAGCACCAGGT & & & & \\
\hline \multirow[t]{2}{*}{$\mathrm{Gq}$} & F: CGATCATGTTTCTGGTAGCGC & 59 & 25 & 401 & 98 \\
\hline & R: CAGATTGTACTCCTTCAGGTTCAGC & & & & \\
\hline \multirow[t]{2}{*}{ Gs } & F: ATCATCTTCGTGGTGGCC & 59 & 18 & 407 & 99 \\
\hline & R: AGTCGTTGAAGACACGGCG & & & & \\
\hline \multirow[t]{2}{*}{ GAPDH } & F: ACCACAGTCCATGCCATCAC & 56 & 18 & 452 & 99 \\
\hline & R: TCCACCACCCTGTTGCTGTA & & & & \\
\hline
\end{tabular}

Abbreviations are: $\mathrm{T}$, annealing temperature; bp, base pairs; $\mathrm{F}$, forward primer; $\mathrm{R}$, reverse primer.

Table 2. Basal Levels of Differentiation and Proliferation Markers in the Cultures of MOB and AOB

\begin{tabular}{lcc}
\hline \hline Markers & \multicolumn{2}{c}{ Osteoblasts } \\
\cline { 2 - 3 } & MOB & AOB \\
\hline ALP activity $(\times 10 \mu \mathrm{mol} / \mathrm{min} / \mathrm{mg}$ protein $)$ & $1.12 \pm 0.081$ & $0.78 \pm 0.051^{*}$ \\
{$\left[{ }^{3} \mathrm{H}\right]$ prolin incorporation $\left(\times 10^{-4} \mathrm{dpm} /\right.$ well $)$} & $1.02 \pm 0.052$ & $0.77 \pm 0.037^{*}$ \\
Area of BN $\left(\mathrm{mm}^{2} /\right.$ well $)$ & $2.32 \pm 0.120$ & $1.56 \pm 0.082^{*}$ \\
Number of BN $\left(\times 10^{-1}\right.$ colony/well $)$ & $2.25 \pm 0.192$ & $1.61 \pm 0.059^{*}$ \\
Calcium content $\left(\times 10^{-1} \mu \mathrm{g} /\right.$ well $)$ & $1.67 \pm 0.033$ & $1.01 \pm 0.028^{*}$ \\
DNA synthesis $\left(\times 10^{-3} \mathrm{dpm} /\right.$ well $)$ & $9.12 \pm 0.226$ & $5.64 \pm 0.154^{*}$ \\
\hline
\end{tabular}

Details are described in MATERIALS AND METHODS. Each value represents mean \pm S.D. $(n=4) .{ }^{*} p<0.001$ compared with that of MOB $(n=4)$. The experiment was repeated twice and the results were essentially the same as those depicted.

viously. ${ }^{18,19)}$

Reverse Transcription-Polymerase Chain Reaction (RT-PCR) Analysis — At the beginning of day 6 , the total RNA of the cells cultured in a 100$\mathrm{mm}$ dish was extracted using TRI ZOL reagent (Invitrogen) based on the acid guanidine thiocyanate and phenol/chloroform method. Aliquots containing $2 \mu \mathrm{g}$ of total RNA were used for the first-strand cDNA synthesis with M-MLV reverse transcriptase (Wako Pure Chemical Industries) in a final mixture of $20 \mu \mathrm{l}$ according to the manufacturer's recommendations. The RT was carried out at $37^{\circ} \mathrm{C}$ for $60 \mathrm{~min}$, and terminated by a $5-\mathrm{min}$ heating at $95^{\circ} \mathrm{C}$ and subsequent cooling down to $4^{\circ} \mathrm{C}$. The RT product for each gene was amplified by PCR using Taq DNA polymerase (Takara, Tokyo, Japan) and a pair of gene-specific primers as shown in Table 1 in a final mixture of $50 \mu$ laccording to the manufacturer's recommendations. Glyceraldehyde-3-phosphate dehydrogenase (GAPDH) was used as an internal control. PCR started with a 5 -min denaturation at $94^{\circ} \mathrm{C}$, followed by $18-25$ cycles of amplification, extension at $72^{\circ} \mathrm{C}$ and holding phase at $4{ }^{\circ} \mathrm{C}$. We carried out preliminary experiments to determine the number of cycles that provided submaximal amplification of each gene (data not shown). Aliquots of PCR products were run on $2 \%$ polyacrylamide gels and stained with SYBR GREEN.

Statistical Analysis — Data were analyzed by Student's $t$-test or by one-way analysis of variance (ANOVA), followed by Dunnett's multiple comparison test. $p<0.001$ was considered significant. All data were presented as the means standard deviation of four cultures.

\section{RESULTS}

Age-Related Changes in the Effects of $\mathrm{Al}^{3+}$ on the Markers for Differentiation and Proliferation of Osteoblasts

Table 2 shows the basal levels of markers for 

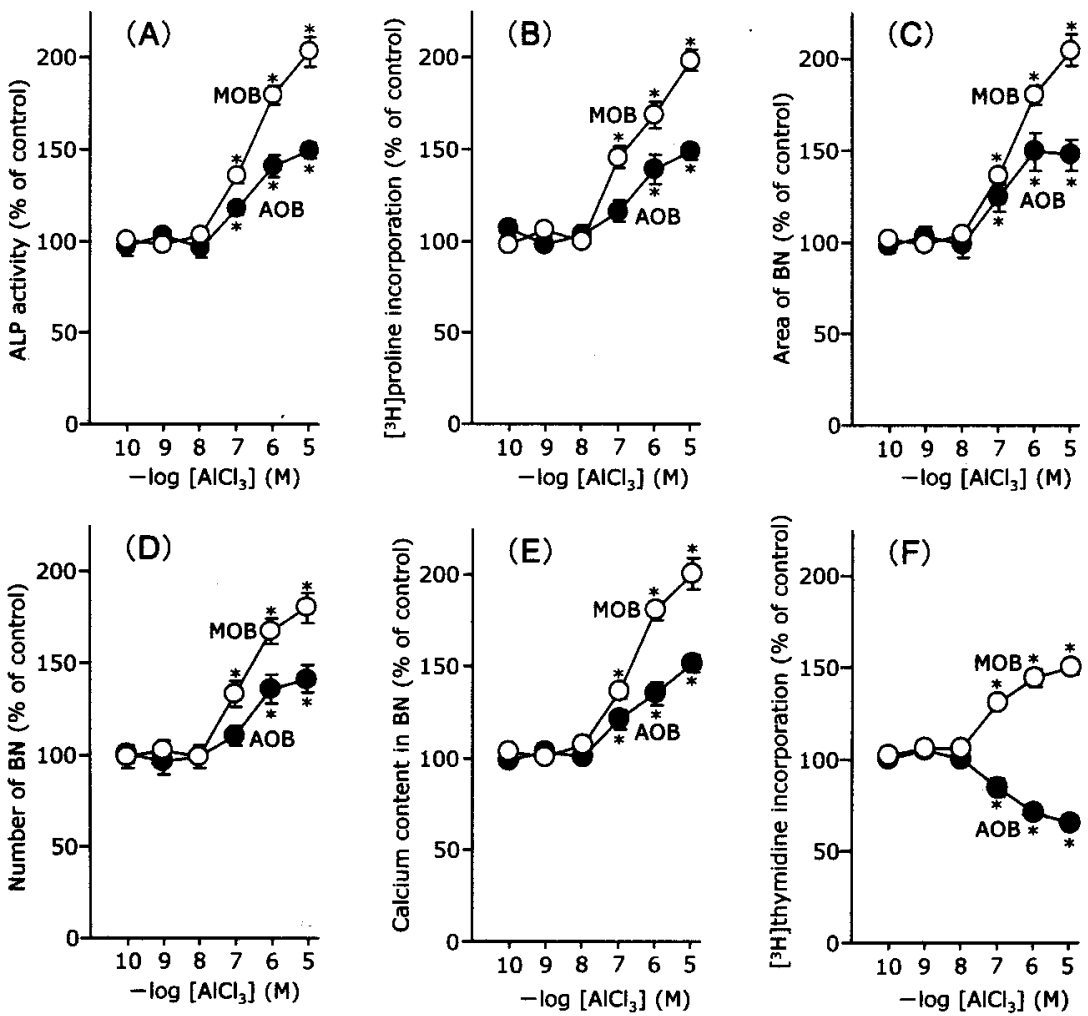

Fig. 1. Effects of $\mathrm{Al}^{3+}$ on the Differentiation and Proliferation Markers of Osteoblasts in the Cultures of MOB and $\mathrm{AOB}$

$\mathrm{MOB}(\mathrm{O})$ and $\mathrm{AOB}(\bullet)$ were treated with various concentrations of $\mathrm{Al}^{3+}$ for $24 \mathrm{hr}$ on day 5 . The activity of ALP (A) and the rate of $\left.{ }^{3} \mathrm{H}\right]$ proline incorporation into the collagenase-digestible proteins (B) were measured on day 7. The total area (C) and number (D) of BN and calcium content (E) were measured on day 28 . The rate of $\left[{ }^{3} \mathrm{H}\right]$ thymidine incorporation into the cells $(\mathrm{F})$ was measured on day 6 . Each point and vertical bar represents mean value and S.D. $(n=4)$, respectively. Basal levels of all markers were shown in Table 2. The experiment was repeated twice and the results were essentially the same as those depicted. $* p<0.001$, versus control.

the differentiation and proliferation. The activity of ALP, the rate of $\left[{ }^{3} \mathrm{H}\right]$ proline incorporation into collagenase-digestible proteins, the total area and number of $\mathrm{BN}$ and the content of calcium in $\mathrm{BN}$, which are markers for differentiation, and the rate of $\left[{ }^{3} \mathrm{H}\right]$ thymidine incorporation into the cells, which is a marker for proliferation, were significantly lower in $\mathrm{AOB}$ than in MOB. By the treatment with $\mathrm{Al}^{3+}$, all markers for differentiation increased dose-dependently at a concentration range of $10^{-7}-10^{-5} \mathrm{M}$ in the cultures of both MOB and AOB (Figs. 1A-1E). The maximal values obtained at $10^{-5} \mathrm{M}$ were approximately 2.0 and 1.5 -fold greater than control values in the cultures of MOB and AOB, respectively, suggesting the age-dependent decrease in the stimulatory effect of $\mathrm{Al}^{3+}$ on the differentiation of osteoblasts. By the treatment with $\mathrm{Al}^{3+}$, the rate of $\left[{ }^{3} \mathrm{H}\right]$ thymidine incorporation into the cells increased in the cultures of MOB but decreased in those of $\mathrm{AOB}$ at a concentration range of $10^{-7}-10^{-5} \mathrm{M}$ (Fig. 1F).

\section{Effect of $\mathrm{Al}^{3+}$ on $\mathrm{PGE}_{2}$ Production by MOB and AOB}

Since the functions of osteoblasts can be modified by $\mathrm{PGE}_{2}$ in an autocrine manner as well as a paracrine manner, $\mathrm{Al}^{3+}$ may regulate differentiation and proliferation of MOB and AOB by affecting the rate of $\mathrm{PGE}_{2}$ secretion from these cells. It is, however, not likely because no significant change was observed in the amount of $\mathrm{PGE}_{2}$ secreted into the medium after the treatment with various concentrations of $\mathrm{Al}^{3+}$ (Fig. 2).

\section{Effect of $\mathrm{Al}^{3+}$ on Differentiation and Proliferation of Osteoblasts in the Presence of an $\mathbf{E P}_{1}$ Agonist}

Figure 3 shows the effect of $\mathrm{Al}^{3+}$ on the markers for differentiation and proliferation of osteoblasts in the presence of $10^{-6} \mathrm{M} 17$-phenyl- $\omega$-trinor- $\mathrm{PGE}_{2}$, a selective $\mathrm{EP}_{1}$ agonist, in the cultures of $\mathrm{MOB}$ and $\mathrm{AOB}$. In the absence of $\mathrm{Al}^{3+}$, the $\mathrm{EP}_{1}$ agonist increased all markers for differentiation by 70 to $80 \%$ and decreased $\left[{ }^{3} \mathrm{H}\right]$ thymidine incorporation into the cells by approximately $40 \%$ in the cultures of MOB, 


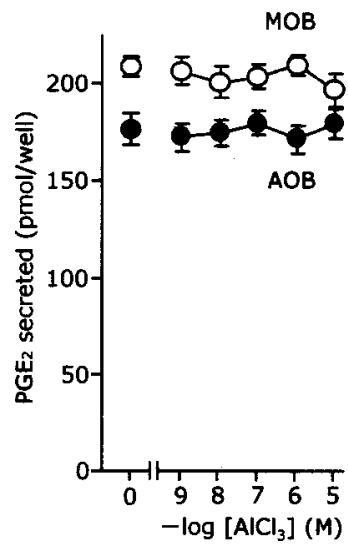

Fig. 2. Effects of $\mathrm{Al}^{3+}$ on the Secretion of $\mathrm{PGE}_{2}$ in the Cultures of $\mathrm{MOB}$ and $\mathrm{AOB}$

MOB $(O)$ and AOB $(\bigcirc)$ were treated with various concentrations of $\mathrm{Al}^{3+}$ for $24 \mathrm{hr}$ on day 5 , and then the amount of $\mathrm{PGE}_{2}$ in the medium was determined by RIA. Each point and vertical bar represents mean value and S.D. $(n=4)$, respectively. The experiment was repeated twice and the results were essentially the same as those depicted. but no changes were observed in those of AOB probably due to the lack of $\mathrm{EP}_{1}$. In the presence of the $\mathrm{EP}_{1}$ agonist, $\mathrm{Al}^{3+}$ dose-dependently stimulated all differentiation markers in the cultures of both $\mathrm{MOB}$ and AOB (Figs. 3A-3E) at a concentration range of $10^{-7}-10^{-5} \mathrm{M}$, while it was stimulatory and inhibitory to $\left[{ }^{3} \mathrm{H}\right]$ thymidine incorporation into MOB and into $\mathrm{AOB}$, respectively, at the same concentration range. These results suggest that the effect of $\mathrm{Al}^{3+}$ is independent of $\mathrm{EP}_{1}$. The effects of $\mathrm{Al}^{3+}$ were abolished by the pretreatment of the cells with pertissis toxin (PTX), an inhibitor of $G_{i}$ protein, indicating the involvement of a receptor coupled with $\mathrm{G}_{\mathrm{i}}$ protein in the signaling pathway. Figure 4 shows the mRNA expression of $\mathrm{PGE}_{2}$ receptor subtypes and $\mathrm{G}$ proteins in MOB and AOB. The expression levels of $E_{1}$ and $G_{q}$ protein mRNAs were significantly lower in $\mathrm{AOB}$ than in MOB, while no difference was ob-
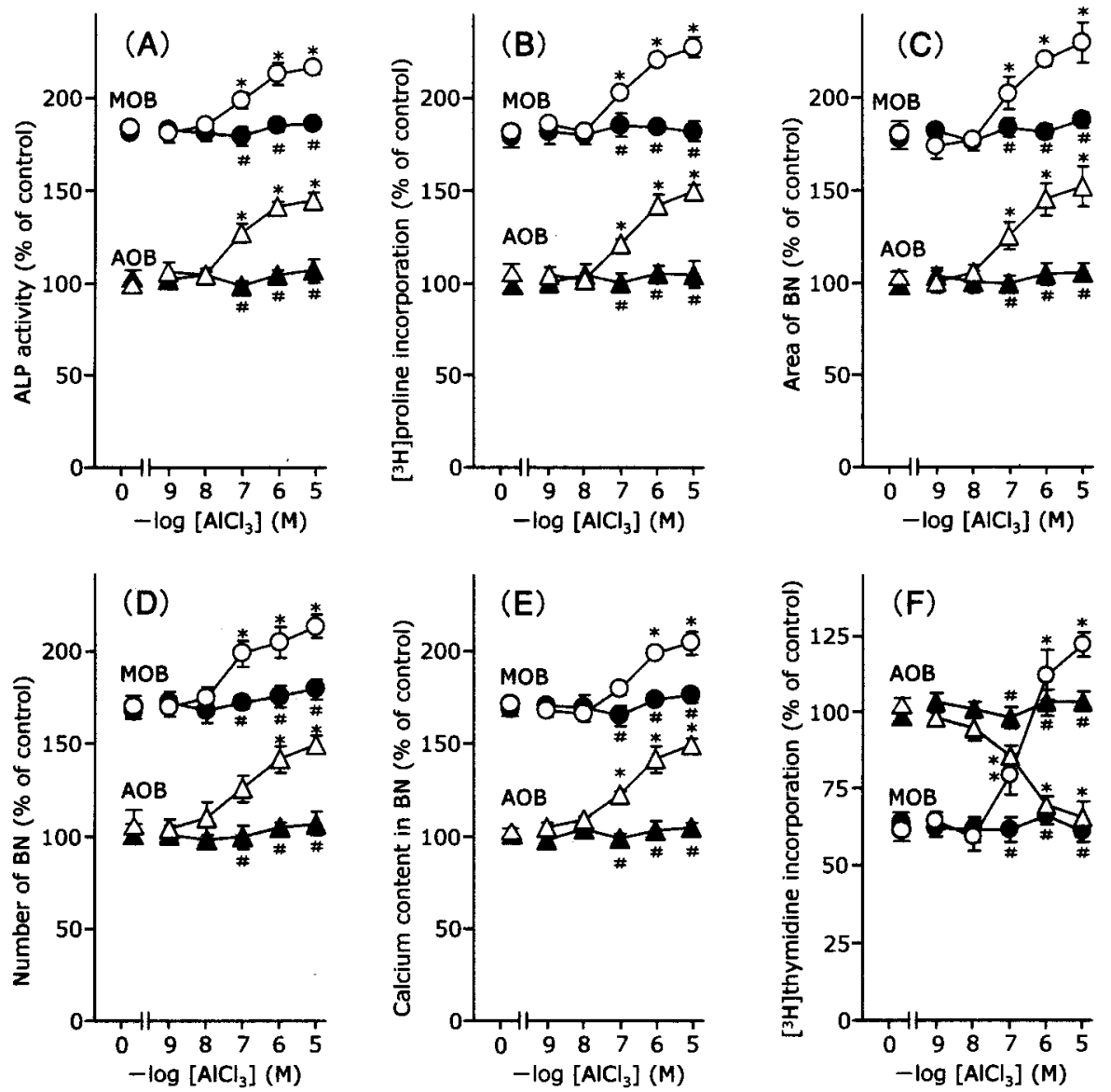

Fig. 3. Effects of $\mathrm{Al}^{3+}$ on Differentiation and Proliferation of $\mathrm{MOB}$ and $\mathrm{AOB}$ in the Presence of $\mathrm{EP}_{1}$ Agonist

MOB (circle symbols) and AOB (triangle symbols) were pretreated with vehicle (open symbols) or PTX (100 ng/ml, closed symbols) during the last $12 \mathrm{hr}$ of day 4 and then incubated with $10^{-6} \mathrm{M} 17$-phenyl- $\omega$-trinor-PGE ${ }_{2}$ and various concentrations of $\mathrm{Al}^{3+}$ for $24 \mathrm{hr}$. The activity of ALP (A) and the rate of $\left[{ }^{3} \mathrm{H}\right]$ proline incorporation into the collagenase-digestible proteins (B) were measured on day 7. The total area (C) and number (D) of BN and calcium content (E) were measured on day 28. The rate of $\left[{ }^{3} \mathrm{H}\right]$ thymidine incorporation into the cells $(\mathrm{F})$ was measured on day 6 . Each point and vertical bar represents mean value and S.D. $(n=4)$, respectively. The experiment was repeated twice and the results were essentially the same as those depicted. ${ }^{*} p<0.001$, versus control. $\# p<0.001$, between vehicle and PTX treatments. 
(A) $\mathrm{EP}_{1}$ signaling pathway

$$
\begin{aligned}
& \text { MOB } \quad A O B \\
& \text { CT } \mathrm{Al}^{3+} \mathrm{CT} \mathrm{Al}^{3+}
\end{aligned}
$$

$E P_{1}$
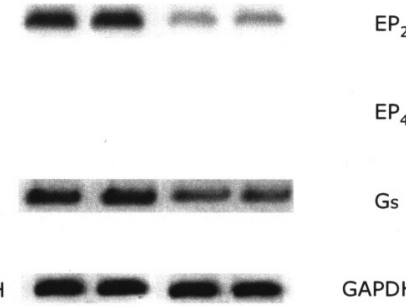

(B) $\mathrm{EP}_{2} / \mathrm{EP}_{4}$ signaling pathway

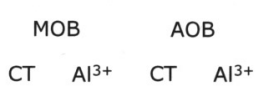

$\mathrm{EP}_{2}$

$\mathrm{EP}_{4}$

Gs

GAPDH

Fig. 4. Effects of $\mathrm{Al}^{3+}$ on mRNA Expression Levels of $\mathrm{PGE}_{2}$ Receptor Subtypes and G Protein Subtypes in the Cultures of MOB and AOB

The cells were treated with vehicle or $10^{-6} \mathrm{M} \mathrm{Al}^{3+}$ for $24 \mathrm{hr}$ on day 5 . At the beginning of day 6 , whole cell RNA was subjected to RT-PCR using specific primers for $\mathrm{PGE}_{2}$ receptor subtypes $\left(\mathrm{EP}_{1}, \mathrm{EP}_{2}\right.$ and $\left.\mathrm{EP}_{4}\right)$ or $G$ protein subtypes $\left(G_{q}\right.$ protein and $G_{s}$ protein) as described in Materials and Methods. The experiment was repeated twice and the results were essentially the same as those depicted. (A) $\mathrm{EP}_{1}$ signaling pathway, (B) $\mathrm{EP}_{2} / \mathrm{EP}_{4}$ signaling pathway. CT, treatment with vehicle; $\mathrm{Al}^{3+}$, treatment with $10^{-6} \mathrm{M} \mathrm{Al}^{3+}$. served in the expression levels of $\mathrm{EP}_{2}, \mathrm{EP}_{4}$ and $\mathrm{G}_{\mathrm{s}}$ protein mRNAs between MOB and AOB. Treatment with $\mathrm{Al}^{3+}$ didn't affect the expression levels of these receptor subtypes and $\mathrm{G}$ proteins.

\section{Effect of $\mathrm{Al}^{3+}$ on Differentiation and Proliferation of Osteoblasts in the Presence of $\mathbf{E P}_{2} / \mathbf{E P}_{4}$ Agonist}

Figure 5 shows the concentration dependency of the effect of $\mathrm{Al}^{3+}$ on markers for differentiation and proliferation of osteoblasts in the presence of $10^{-6} \mathrm{M}$ 11-deoxy-PGE 1 , a selective $\mathrm{EP}_{2} / \mathrm{EP}_{4}$ agonist, in the cultures of MOB and AOB. In the absence of $\mathrm{Al}^{3+}$, the $\mathrm{EP}_{2} / \mathrm{EP}_{4}$ agonist suppressed the all differentiation markers by $30-50 \%$ (Figs. 5A-5E), while it stimulated $\left[{ }^{3} \mathrm{H}\right]$ thymidine incorporation into the cells by $50 \%$ (Fig. $5 \mathrm{~F}$ ). $\mathrm{Al}^{3+}$ dose-dependently stimulated all differentiation markers and suppressed $\left[{ }^{3} \mathrm{H}\right]$ thymidine incorporation into the cells at the concentration range of $10^{-7}-10^{-5} \mathrm{M}$ in the presence of
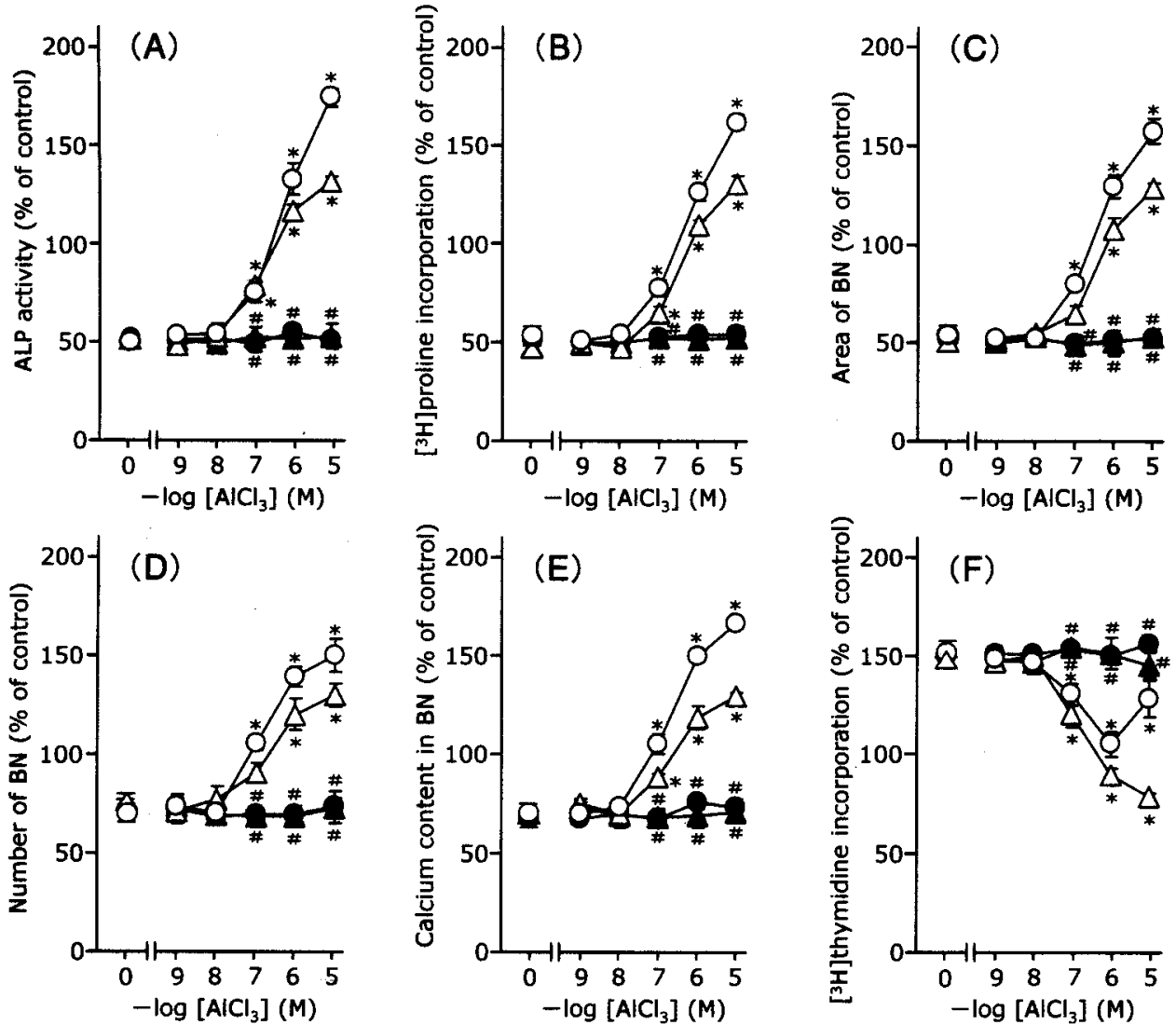

Fig. 5. Effects of $\mathrm{Al}^{3+}$ on Differentiation and Proliferation of $\mathrm{MOB}$ and $\mathrm{AOB}$ in the Presence of $\mathrm{EP}_{2} / \mathrm{EP}_{4}$ Agonist

MOB (circle symbols) and AOB (triangle symbols) were pretreated with vehicle (open symbols) or PTX ( $100 \mathrm{ng} / \mathrm{ml}$, closed symbols) during the last $12 \mathrm{hr}$ of day 4, and then incubated with $10^{-6} \mathrm{M}$ 11-deoxy-PGE ${ }_{1}$ and various concentrations of $\mathrm{Al}^{3+}$ for $24 \mathrm{hr}$. The activity of ALP (A) and the rate of $\left[{ }^{3} \mathrm{H}\right]$ proline incorporation into the collagenase-digestible proteins (B) were measured on day 7. The total area $(\mathrm{C})$ and number (D) of BN and calcium content (E) were measured on day 28. The rate of $\left[{ }^{3} \mathrm{H}\right]$ thymidine incorporation into the cells $(\mathrm{F})$ was measured on day 6 . Each point and vertical bar represents mean value and S.D. $(n=4)$, respectively. The experiment was repeated twice and the results were essentially the same as those depicted. ${ }^{*} p<0.001$, versus control. $\# p<0.001$, between vehicle and PTX treatments. 

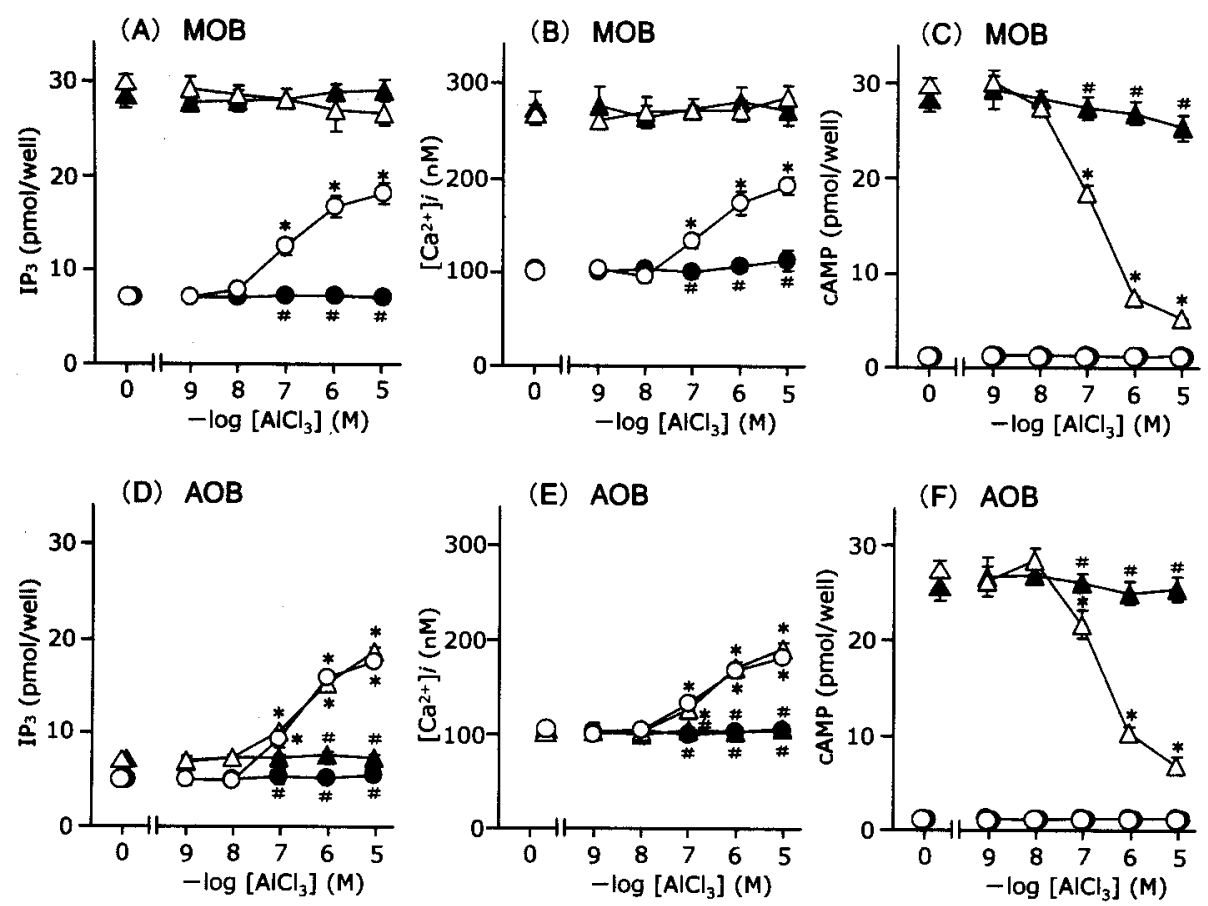

Fig. 6. Effects of $\mathrm{Al}^{3+}$ on Intracellular Levels of $\mathrm{IP}_{3}$ Production, $\left[\mathrm{Ca}^{2+}\right]_{i}$, and cAMP Accumulation in the Cultures of MOB and AOB MOB (A-C) and AOB (D-E) were treated with vehicle (open symbols) or PTX (100 ng/ml, closed symbols) during the last $12 \mathrm{hr}$ of day 4 . For the determination of the levels of $\mathrm{IP}_{3}(\mathrm{~A}, \mathrm{D})$ and $\left[\mathrm{Ca}^{2+}\right]_{i}(\mathrm{~B}, \mathrm{E})$, the cells were stimulated with various concentrations of $\mathrm{Al}^{3+}$ for 15 sec in the presence (triangle symbols) or absence (circle symbols) of $10^{-6} \mathrm{M} 17$-phenyl- $\omega$-trinor-PGE 2 . For the determination of the level of cAMP (C, F), the cells were stimulated with various concentrations of $\mathrm{Al}^{3+}$ for $20 \mathrm{~min}$ in the presence (triangle symbols) or absence (circle symbols) of $10^{-6} \mathrm{M} 11-\mathrm{deoxy}-\mathrm{PGE}_{1}$. Each point and vertical bar represents mean value and S.D. $(n=4)$, respectively. The experiment was repeated twice and the results were essentially the same as those depicted. ${ }^{*} p<0.001$, versus control. $\# p<0.001$, between vehicle and PTX treatments.

the $\mathrm{EP}_{2} / \mathrm{EP}_{4}$ agonist and these effects of $\mathrm{Al}^{3+}$ were abolished by the pretreatment of the cells with PTX in the cultures of MOB and AOB (Figs. 5A-5F). These results suggest that $\mathrm{Al}^{3+}$ may regulate the $\mathrm{EP}_{2} /$ $\mathrm{EP}_{4}$ pathway by signaling through the receptor coupled with $\mathrm{G}_{\mathrm{i}}$ protein.

\section{Effects of $\mathrm{Al}^{3+}$ on the Production of $\mathrm{IP}_{3},\left[\mathrm{Ca}^{2+}\right]_{i}$ and the Accumulation of CAMP}

Crosstalk between the signaling pathways for $\mathrm{Al}^{3+}$ and $\mathrm{PGE}_{2}$ was studied by measuring the production of $\mathrm{IP}_{3},\left[\mathrm{Ca}^{2+}\right]_{i}$ and the accumulation of cAMP after the treatment with $\mathrm{Al}^{3+}$ (Fig. 6). The treatment of the cells with $\mathrm{EP}_{1}$ agonist increased the production of $\mathrm{IP}_{3}$ and $\left[\mathrm{Ca}^{2+}\right]_{i}$ in the cultures of MOB (Figs. 6A and 6B), but not in those of AOB (Figs. 6D and $6 \mathrm{E}$ ). The addition of $\mathrm{Al}^{3+}$ to the cultures increased those parameters in the presence and absence of the $\mathrm{EP}_{1}$ agonist in the cultures of $\mathrm{AOB}$ (Figs. 6D and $6 \mathrm{E})$, but only in its absence in those of MOB (Figs. 6A and 6B). The stimulatory effect of $\mathrm{Al}^{3+}$ was abolished by the pretreatment of the cells with PTX. These results suggest that the $\mathrm{Al}^{3+}$ signal is mediated by the $G_{i}$ protein-coupled receptor, but not by
$\mathrm{EP}_{1}$, and that the signals through the $\mathrm{G}_{\mathrm{i}}$ proteincoupled receptor and those through $\mathrm{EP}_{1}$ activate the same pool of PI-PLC. The $\mathrm{EP}_{2} / \mathrm{EP}_{4}$ agonist increased cAMP production in the cultures of both $\mathrm{MOB}$ and AOB (Figs. 6C and 6F), and the stimulatory effect was dose-dependently reduced by the addition of $\mathrm{Al}^{3+}$ in the absence of PTX, but not in its presence. These results suggest that $\mathrm{Al}^{3+}$ suppresses adenylyl cyclase activity induced by the $\mathrm{EP}_{2} / \mathrm{EP}_{4}$-mediated signal through the $\mathrm{G}_{\mathrm{i}}$ protein-coupled receptor.

\section{DISCUSSION}

Previous studies concerning the effect of $\mathrm{Al}^{3+}$ on osteoblastic functions mainly focused on the mechanism for the development of osteomalacia, since $\mathrm{Al}^{3+}$ at high concentrations disturbs normal deposition of calcium phosphate, leading to the incomplete mineralization of bone tissue. ${ }^{1-9)}$ It has been shown in the present study that the short term treatment of calvarial osteoblasts with $\mathrm{Al}^{3+}$ at $10^{-7} \mathrm{M}$ increases the $\mathrm{BN}$ formation. Serum levels of $\mathrm{Al}^{3+}$ in normal subjects are in the order of $10^{-7} \mathrm{M}$, while those in 
patients with end-stage renal disease undergoing hemodialysis therapy often exceed $5 \times 10^{-6} \mathrm{M} \cdot .^{23,24)}$ It is therefore possible that the physiological level of $\mathrm{Al}^{3+}$ serves as a positive regulator of bone formation although in vivo experiments in which the circulating level of $\mathrm{Al}^{3+}$ is maintained at a low concentration range will be required to prove this assumption.

We have proposed a model for the signal transduction pathway for the $\mathrm{PGE}_{2}$-induced increase in $\mathrm{BN}$ formation in the primary cultures of osteoblasts. ${ }^{18,19)}$ According to the model, $\mathrm{PGE}_{2}$ evokes cellular responses of osteoblasts via two independent pathways mediated by $\mathrm{EP}_{1}$ and $\mathrm{EP}_{2} / \mathrm{EP}_{4}$. Binding of $\mathrm{PGE}_{2}$ to $\mathrm{EP}_{2} / \mathrm{EP}_{4}$ leads to the $\mathrm{G}_{\mathrm{s}}$ protein-mediated activation of adenylyl cyclase, resulting in the increase in the production of cAMP which is a suppressor of bone formation by osteoblasts. On the other hand, binding of $\mathrm{PGE}_{2}$ to $\mathrm{EP}_{1}$ leads to the $\mathrm{G}_{\mathrm{q}}$ protein-mediated activation of PI-PLC to produce $\mathrm{IP}_{3}$, which binds to its receptor on the surface of endoplasmic reticulum to cause the $\mathrm{Ca}^{2+}$ release to cytoplasm. Elevation of $\left[\mathrm{Ca}^{2+}\right]_{i}$ leads to the activation of $\mathrm{CaM}$, which stimulates the formation of $\mathrm{BN}$ by an unknown mechanism. Activated CaM also causes an increase in the activity of phosphodiesterase, resulting in the hydrolysis of cAMP to extinguish the $\mathrm{EP}_{2} / \mathrm{EP}_{4}$-mediated signal of $\mathrm{PGE}_{2}$. We propose here a model for the mechanism for induction of $\mathrm{BN}$ formation by $\mathrm{Al}^{3+}$ and its relationship with the signaling pathways for $\mathrm{PGE}_{2}$, which is illustrated in Fig. 7. The activation of PI-PLC by $\mathrm{Al}^{3+}$ seems to be mediated through a receptor coupled with $\mathrm{G}_{\mathrm{i}}$ protein, because the stimulatory effect of the cation is abolished by the pretreatment of the cells with PTX. $\mathrm{EP}_{1}$ doesn't seem to be involved in the $\mathrm{Al}^{3+}$-induced PI-PLC activation because the cation increased the differentiation markers in $\mathrm{AOB}$, which lacks $\mathrm{EP}_{1}$. $\mathrm{Al}^{3+}$ also seems to regulate the adenylyl cyclase activity induced by a signal through $\mathrm{EP}_{2} / \mathrm{EP}_{4}$ through the receptor coupled with $\mathrm{G}_{\mathrm{i}}$ protein. The identity of the receptor coupled with $\mathrm{G}_{\mathrm{i}}$ protein is not known at present. House et al. ${ }^{25)}$ have recently shown that stromal cells, potentially representing osteoblastic functions, expressed the calcium sensing receptor (CaSR), raising a possibility that the receptor is expressed and plays a functional role in the cells of osteoblast lineage. In fact, elevated levels of extracellular $\mathrm{Ca}^{2+}$ have several physiologically relevant actions on osteoblasts such as the stimulation of their proliferation and chemotaxis, ${ }^{26-28)}$ and modulation of

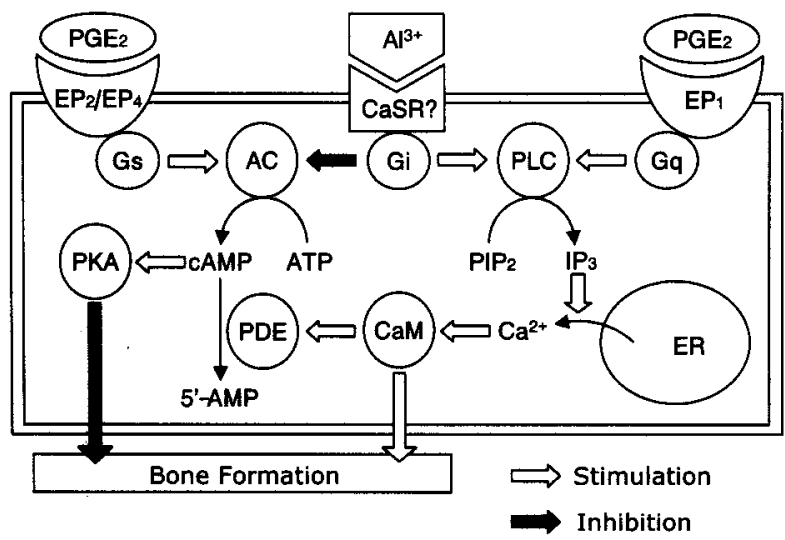

Fig. 7. The Signal Transduction Pathway for $\mathrm{Al}^{3+}$-Induced Cellular Responses in Rat Calvarial Osteoblasts

Binding of $\mathrm{PGE}_{2}$ or 11-deoxy- $\mathrm{PGE}_{1}$ to $\mathrm{EP}_{2} / \mathrm{EP}_{4}$ leads to the activation of adenylyl cyclase (AC) to produce cAMP, which inhibits bone formation through the activation of CAMP-dependent protein kinase (PKA). Binding of $\mathrm{PGE}_{2}$ or 17-phenyl- $\omega$-trinor- $\mathrm{PGE}_{2}$ to $\mathrm{EP}_{1}$ leads to the activation of PI-PLC to produce $\mathrm{IP}_{3}$, which binds to its receptor on the surface of endoplasmic reticulum (ER), resulting in the release of $\mathrm{Ca}^{2+}$. $\mathrm{Ca}^{2+}$ causes the activation of bone formation through the activation of $\mathrm{CaM}$, and also activates a phosphodiesterase (PDE), which suppresses the signaling through $\mathrm{EP}_{2} / \mathrm{EP}_{4}$ by degrading cAMP. $\mathrm{Al}^{3+}$ increases bone formation due to an inhibition of $\mathrm{EP}_{2} / \mathrm{EP}_{4}$ signaling pathway and an activation of $\mathrm{EP}_{1}$ signaling pathway through the activation of $\mathrm{G}_{\mathrm{i}}$ protein.

the several intracellular second messenger systems. ${ }^{11,12,29)}$ Although we have identified CaSR mRNA in MOB and AOB by RT-PCR (Kaneki et $a l$., unpublished data), it is not known at present if the receptor is functional in the stimulation of $\mathrm{BN}$ formation by $\mathrm{Al}^{3+}$. Further work will be required to clarify this point.

\section{REFERENCES}

1) Jeffery, E. H., Abreo, K., Burgess, E., Cannata, J. and Greger, J. L. (1996) Systemic aluminum toxicity: effects on bone, hematopoietic tissue, and kidney. J. Toxicol. Environ. Health, 48, 649-665.

2) Bushinsky, D. A. (1997) Bone disease in moderate renal failure: cause, nature and prevention. Annu. Rev. Med., 48, 167-176.

3) Fournier, A., Oprisiu, R., Hottelart, C., Yverneau, P. H., Ghazali, A., Atik, A., Hedri, H., Said, S., Sechet, A., Rasolombololona, M., Abighanem, O., Sarraj, A., El Esper, N., Moriniere, P., Boudailliez, B., Westeel, P. F., Achard, J. M. and Pruna, A. (1998) Renal osteodystrophy in dialysis patients: diagnosis and treatment. Artif. Organs., 22, 530-557.

4) Malluche, H. H. (2002) Aluminum and bone disease in chronic renal failure. Nephrol. Dial. Trans- 
plant., 17, 21-24.

5) Cournot-Witmer, G., Zingraff, J., Plachot, J. J., Escaig, F., Lefevre, R., Boumati, P., Bourdeau, A., Garabedian, M., Galle, P., Bourdon, R., Drueke, T. and Balsan, S. (1981) Aluminum localization in bone from hemodialyzed patients: relationship to matrix mineralization. Kidney Int., 20, 375-378.

6) Chazan, J. A., Libbey, N. P., London, M. R., Pono, L. and Abuelo, J. G. (1991) The clinical spectrum of renal osteodystrophy in 57 chronic hemodialysis patients: a correlation between biochemical parameters and bone pathology findings. Clin. Nephrol., 35, 78-85.

7) Nordal, K. P., Dahl, E., Halse, J., Aksnes, L., Thomassen, Y. and Flatmark, A. (1992) Aluminum metabolism and bone histology after kidney transplantation: a one-year follow-up study. J. Clin. Endocrinol. Metab., 74, 1140-1145.

8) Ecelbarger, C. A., MacNeil, G. G. and Greger, J. L. (1994) Aluminum retention by aged rats fed aluminum and treated with desferrioxamine. Toxicol. Lett., 73, 249-257.

9) Diaz-Corte, C., Fernandez-Martin, J. L., Barreto, S., Gomez, C., Fernandez-Coto, T., Braga, S. and Cannata, J. B. (2001) Effect of aluminum load on parathyroid hormone synthesis. Nephrol. Dial. Transplant., 16, 742-745.

10) Sprague, S. M., Krieger, N. S. and Bushinsky, D. A. (1993) Aluminum inhibits bone nodule formation and calcification in vitro. Am. J. Physiol., 264, F882F890.

11) Pun, K. K., Ho, P. W. and Lau, P. (1990) Effects of aluminum on the parathyroid hormone receptors of bone and kidney. Kidney Int., 37, 72-78.

12) Lajeunesse, D., Moreau, R., Hobbs, W., Qui, W., Lafond, J. and Guggino, S. E. (1998) Influence of aluminum on the regulation of $\mathrm{PTH}$ - and $1,25(\mathrm{OH})_{2} \mathrm{D}_{3}$-dependent pathways in the rat osteosarcoma cell line ROS 17/2.8. J. Bone Miner. Res., 13, 962-969.

13) Bellows, C. G., Heersche, J. N. and Aubin, J. E. (1999) Aluminum accelerates osteoblastic differentiation but is cytotoxic in long-term rat calvaria cell cultures. Calcif. Tissue Int., 65, 59-65.

14) Lau, K. H., Yoo, A. and Wang, S. P. (1991) Aluminum stimulates the proliferation and differentiation of osteoblasts in vitro by a mechanism that is different from fluoride. Mol. Cell. Biochem., 105, 93-105.

15) Lau, K. H., Utrapiromsuk, S., Yoo, A., Mohan, S., Strong, D. D. and Baylink, D. J. (1993) Mechanism of mitogenic action of aluminum ion on human bone cells: potential involvement of the insulin-like growth factor regulatory system. Arch. Biochem. Biophys., 303, 267-273.
16) Lau, K. H., Goodwin, C., Arias, M., Mohan, S. and Baylink, D. J. (2002) Bone cell mitogenic action of fluoroaluminate and aluminum fluoride but not that of sodium fluoride involves upregulation of the insulin-like growth factor system. Bone, 30, 705-711.

17) Quarles, L. D., Hartle, J. E., 2nd, Middleton, J. P., Zhang, J., Arthur, J. M. and Raymond, J. R. (1994) Aluminum-induced DNA synthesis in osteoblasts: mediation by a G-protein coupled cation sensing mechanism. J. Cell. Biochem., 56, 106-117.

18) Fujieda, M., Kiriu, M., Mizuochi, S., Hagiya, K., Kaneki, H. and Ide, H. (1999) Formation of mineralized bone nodules by rat calvarial osteoblasts decreases with donor age due to a reduction in signaling through $\mathrm{EP}_{1}$ subtype of prostaglandin $\mathrm{E}_{2}$ receptor. J. Cell. Biochem., 75, 215-225.

19) Kaneki, H., Takasugi, I., Fujieda, M., Kiriu, M., Mizuochi, S. and Ide, H. (1999) Prostaglandin $E_{2}$ stimulates the formation of mineralized bone nodules by a cAMP-independent mechanism in the culture of adult rat calvarial osteoblasts. J. Cell. Biochem., 73, 36-48.

20) Peterkofsky, B. and Diegelmann, R. (1971) Use of a mixture of proteinase-free collagenases for the specific assay of radioactive collagen in the presence of other proteins. Biochemistry, 10, 988-994.

21) Lowry, O. H., Roberts, N. R., Wu, M. L., Hixton, W. S. and Crawford, E. J. (1954) The quantitative histochemistry of brain II: enzyme measurements. J. Biol. Chem., 207, 19-37.

22) Grynkiewicz, G., Poenie, M. and Tsien, R. Y. (1985) A new generation of $\mathrm{Ca}^{2+}$ indicators with greatly improved fluorescence properties. J. Biol. Chem., 260, 3440-3450.

23) Parry, R., Plowman, D., Delves, H. T., Roberts, N. B., Birchall, J. D., Bellia, J. P., Davenport, A., Ahmad, R., Fahal, I. and Altmann, P. (1998) Silicon and aluminum interactions in haemodialysis patients. Nephrol. Dial. Transplant., 13, 1759-1762.

24) D'Haese, P. C., Couttenye, M. M., Lamberts, L. V., Elseviers, M. M., Goodman, W. G., Schrooten, I., Cabrera, W. E. and De Broe, M. E. (1999) Aluminum, iron, lead, cadmium, copper, zinc, chromium, magnesium, strontium, and calcium content in bone of end-stage renal failure patients. Clin. Chem., $\mathbf{4 5}$, 1548-1556.

25) House, M. G., Kohlmeier, L., Chattopadhyay, N., Kifor, O., Yamaguchi, T., Leboff, M. S., Glowacki, J. and Brown, E. M. (1997) Expression of an extracellular calcium-sensing receptor in human and mouse bone marrow cells. J. Bone Miner. Res., 12, 1959-1970.

26) Pearce, S. H. and Thakker, R. V. (1997) The calcium-sensing receptor: insights into extracellular 
calcium homeostasis in health and disease. $J$. Endocrinol., 154, 371-378.

27) Godwin, S. L. and Soltoff, S. P. (1997) Extracellular calcium and platelet-derived growth factor promote receptor-mediated chemotaxis in osteoblasts through different signaling pathways. J. Biol. Chem., 272, 11307-11312.

28) Quarles, L. D., Hartle, J. E., 2nd, Siddhanti, S. R.,
Guo, R. and Hinson, T. K. (1997) A distinct cationsensing mechanism in MC3T3-E1 osteoblasts functionally related to the calcium receptor. J. Bone Miner. Res., 12, 393-402.

29) Brown, E. M. and MacLeod, R. J. (2001) Extracellular calcium sensing and extracellular calcium signaling. Physiol. Rev., 81, 239-297. 